\title{
Politics, government health expenditure and infant mortality: Does political party orientation matter?
}

\begin{abstract}
Purpose: Motivated by the scant available evidence we explore the relationship between government political party orientation and infant mortality.

Design/methodology/approach: We apply a panel quantile methodology to a dataset that consists of 15 countries of the G20 group over the period 2000-2018. We control for heterogeneous parameters across countries and quantiles and obtain estimates across the different points of the conditional distribution of the dependent variable.
\end{abstract}

Findings: Our findings support the hypothesis that political party orientation has a significant effect on a population health indicator such as infant mortality. The analysis suggests that, to a great extent, left-wing government parties contribute to better health outcomes - when compared to right and centre political parties - both individually as well as interacted with government health expenditure. Moreover, the impact of redistributing policies appears to be of a paramount importance in alleviating infant mortality while more education and lower unemployment can also contribute to better health outcomes.

Originality: We explore the relationship between the nature of government political party orientation (i.e. right, centre and left) and infant mortality whilst at the same time gauging the mediating effect of party orientation via government health expenditure on infant mortality. Additional aspects of the impact of other control variables such as, income inequality, unemployment, and education on infant mortality are also investigated.

Keywords: health expenditure; infant mortality; panel data 


\section{Introduction}

The literature on the determinants of health outcomes is well developed while there is growing evidence about the impact of social and cultural factors on population health. However, only scant evidence exists about the impact of government political party orientation on health outcomes while the distribution and exercise of power in health policy and systems has received little attention (Shiffman, 2014; Lee, 2015). Although several empirical studies have explored the potential channels through which the nature of political regimes (democratic, autocratic, etc.) affects economic development (e.g., Przeworski et al., 2000; Acemoglu and Robinson, 2006) or health outcomes (e.g. Okada, 2018), studies that investigate the impact of government political party orientation on population health have fallen behind. Given the nature as well as the composition of current democratic societies one would have expected more emphasis to be placed on the policy implications of democratically elected political parties on health outcomes. Rudolf Virchow - one of the most influential figures in social medicine - eloquently summarized that "Medicine is a social science and politics nothing but medicine on a grand scale".

One possible explanation for the limited literature on the impact of politics on health outcomes might relate to the fact that the public health field is mainly dominated by medical researchers who consider politics to be controversial or falling outside their remit. An alternative explanation might also reside in the way most public health research is funded. For instance, Navarro (2008) argues that within the European region most of the funding comes from public sources that are closely related to political parties. It would therefore be unlikely that an incumbent administration of one political party approves research evidence that suggests that parties of the opposite orientation are more effective in improving population health. 
Arguably, the exercise of power might indeed be a feature of actors or institutions that have the ability to shape global health policy (Brown et al., 2006), but at a national level political parties and their concomitant ideologies can be of paramount importance in influencing the equity and universality of public policy (Navarro et al., 2006; Mackenbach, 2014). It is in this sense that the World Health Organization's Director-General suggested that universal health coverage (UHC) is "a political choice" (UN News 2019; WHO 2019).

Politics is a ubiquitous feature of modern societies whilst political views and economic systems differ markedly. The traditional ideological dichotomy between left-wing and right-wing party orientation reflects the degree of government intervention in a market system to either secure social goals or provide more economic freedom and minimal state intervention. In this context, existing social and economic inequalities are believed to be strong predictors of health inequalities whilst increased income inequality is found to adversely affect both health and social outcomes - such as infant mortality, life expectancy, obesity, mental health, trust, level of education and social mobility (Willkison and Pickett, 2010). There is also evidence that political orientation in conjunction with personal and vested interests can have a substantial impact on health policy (Ferrie, 2015; Reijneveld, 2017).

From a policy perspective, the proponents of the view that institutions are closely bound up with the evolution of welfare systems suggest that direct democracies, and federalism, tend to promote a more liberal type of welfare state by vetoing decisions and by steering the central government's direction to the expansion of social expenditure (Immergut, 1992; Wagschal, 1997; Crepaz, 1998; Lijphart, 2012; Castles, 2000; Tsebelis, 2002). In view of the above and the very few studies in the area, such as the one by Korpi (2000) who explored how political traditions and the power relations reflected by class as well as gender affect the nature of the welfare state and the well-being of the population, we feel that there is 
a scope and a pressing need to undertake more studies exploring the impact of politics on health outcomes.

In this direction we attempt to contribute to the existing literature in a number of ways. First, by applying a panel quantile methodology to a dataset that consists of 15 countries of the G20 group over the period 2000-2018, we control for heterogeneous parameters across countries and quantiles and obtain estimates across the different points of the conditional distribution of the health indicator variable. Second, to the best of our knowledge this is the first study that explores the relationship between the nature of government political party orientation (i.e. right, centre and left) and infant mortality whilst at the same time gauges the mediating effect of party orientation via government health expenditure on infant mortality. Additional aspects of the impact of other control variables such as, income inequality, unemployment, and education on infant mortality are also investigated.

Our findings support the hypothesis that political party orientation affects indicators of population health such as infant mortality. Our analysis makes an empirical link between politics and policy by showing that to a great extent left-wing parties via health expenditure outlays produce better health outcomes compared to right and centre oriented political parties. In addition, the impact of redistributing policies (as reflected by the highly significant Gini coefficient) appears to be of a paramount importance in alleviating infant mortality whilst both education and unemployment incrementally reinforce the hypothesis that more education and lower unemployment contribute to better health outcomes.

The remainder of this paper is organized as follows. The second section presents a brief overview of the related literature whilst the third section describes the data and the estimation methodology adopted in this study. The fourth section discusses the estimation results and the final section provides some concluding remarks. 


\section{Relevant literature}

The preponderance of the existing health policy and systems analyses are mainly descriptive (Adam et al., 2012), lacking theoretical foundations that can generate durable intellectual frameworks to analyse health problems in different contexts (Kleinman, 2010), making their suggestions "incoherent and difficult to integrate into foreign policy strategies" (Youde, 2005, p. 205). Gilson and Raphaely (2008) reviewed the policy analysis literature and found that a vigorous assessment of politics and power was rarely studied whilst Storeng and Mishra (2014) observed that health systems strengthening studies focused on technical and managerial issues of health service delivery, whilst no attention was paid to the politics and social relations that affect health systems.

According to the hypothesis of partisan influence on public policy one key factor accounting for significant variations in policy outcomes in constitutional democracies is the party composition of government (see, Hibbs, 1977; Castles, 1982; Cameron, 1984; Hicks and Swank, 1992; Schmidt, 1996; Okada, 2018). In this context, right-wing political parties are associated with significantly lower welfare expenditure whilst left-wing parties tend to encourage higher welfare spending.

A report from the World Health Organization (2008) attributed health inequities to a toxic environment that nurtures poor social policies, unfair economic arrangements, and bad politics. Even though the report conceptualised and collated qualitative evidence on a wide range of social forces and casual processes that can potentially affect health inequity, aspects on competing political priorities, contested political ideologies, or other factors encountered when moving forward health policy agendas, were rather ambiguous (Lee, 2010). In a recent report, the World Health Organizations (2018) used the same rhetoric (i.e., that health inequities are attributed to factors including education, employment status, income level, 
gender and ethnicity) without however making an effort to provide clear policy insights relating to specific political or ideological persuasion.

Ottersen et al. (2014) defined the "global political determinants of health as the norms, policies, and practices that arise from global interactions among entities (states, transnational corporations, and civil society organisations, among others) with different interests and degrees of power" (p.630). The existing health reports in the area have to a great extent failed to "consider the need to better understand empirically how power is expressed in global health governance" (Marten, et al., p. 2207).

Developing interdisciplinary research that can systematically explore issues relating to inequity and political power or generate a decent dialogue between global health researchers requires that humanities and social sciences are combined (Ooms, 2014). Despite the fact that over the past few years there has been a growing interest in social-scientific scholarship on questions of power and politics in global health (Hansen et al., 2013; Storeng and Mishra, 2014; Gomez, 2016; Parker and Garcia, 2019), there are voices that are calling for political science "to take global health policy issues more seriously, while the global public health community needs to do the same for political science, specifically on issues of institutional design and governance" (Gomez, 2016, p. 4).

Despite the fact that extensive theoretical research has been conducted on how political traditions affect health policy, hardly any empirical studies have emerged that explore the impact of political party orientation on health outcomes. At a policy level, the evidence is readily available and as Navarro (2006) argues, parties promoting social policies and a fairer distribution of income have been more successful in improving health population compared to parties whose policies are devoid of such a commitment. On the empirical front, single-country evidence on the health effects of political party orientation (see, McGuire 2010; Scott-Samuel et al., 2014; Hiam et al., 2017; Watkins et al., 2017) can offer useful 
insights, but internationally comparative studies can provide a more holistic analysis by transcending the specificities of individual countries. Muntaner et al. (2011) explored four key political features i.e., democracy, welfare state, left-of-centre political tradition and globalisation, and found that a) a democracy may be health-promoting due to the inherent ability of the electorate to use their voting power when faced with unpopular policies, b) the left-of-centre political tradition is directly associated with a welfare state which promotes better health outcomes through policies that reduce social, economic and health inequalities (Rowlingson, 2011), and c) globalisation, as this is reflected by the emergence of free-trade and neoliberal policies, is advocated by right-wing political entities the policies of which exacerbate population health outcomes. In the same spirit, Barnish and Turner (2017) concluded that a generous welfare state, left-of-centre democratic political tradition, and democracy, appear to be positively affecting population health whilst the evidence on globalisation may be less conclusive.

Moreover, another study using data for various OECD economies governed mainly by social democratic parties (Sweden, Norway, Denmark, Finland and Austria) suggested that their commitment to redistributive policies as measured by the average Gini coefficient over the last 10 years of the study period (which was 0.22) (LIS, 2006) provided universal health care coverage, and social benefits to all citizens (ranging from $30 \%$ of GDP for social public expenditure to $7.2 \%$ of GDP for the average public health care expenditure over the last 10 years of the study period). More recent studies suggest that Nordic countries rank high among OECD countries in terms of per capita expenditure on health (averaging $10.3 \%$ of GDP) whereas Austrian health expenditure in 2016 was 10.4\% of GDP respectively (OECD 2017; Morgan et al. 2017). In this context, Raphael and Bryant (2004) argue that social democratic parties nurture policies that support women's health and wellbeing, paid maternity leave, early child education, childcare, low crime, participation of women in government, and home 
care services. On the other hand, those economies (i.e., Italy, Netherlands, Germany, Belgium and France) that have been less committed to redistributive policies (average Gini coefficient of 0.30 ) than social democrats, have been mainly governed by conservative parties or Christian democratic parties for most of the period from 1950 to 2000. Indicatively, the average public social expenditure and average public health care expenditure were $28 \%$ and $6.4 \%$ of GDP respectively (Bambra, 2005). Recently the average public heath expenditure in these countries has increased further registering 8.5\% of GDP (Morgan et al, 2017).

Furthermore, countries mainly run by liberal or conservative parties of a liberal persuasion, (such as the UK, Ireland, Canada and the USA) appear to be adopting policies that are redistributive in nature (the group average Gini coefficient was 0.32 ) whilst public social expenditures are much lower than in the countries governed by social democratic and Christian democratic parties. In particular, average public social expenditure was $24 \%$ of GDP, whereas the average public health care expenditure amounted to 5.8\% of GDP (EspingAndersen, 1990). The picture however concerning the respective economies appears to have changed dramatically as more recent data suggests that the average health expenditure has doubled, reaching $11.6 \%$ of GDP (OECD 2017).

Countries governed for a considerable period of time by conservative dictatorships (such as Spain, Portugal Greece) during the period of the study (1950-2000) were characterized by unequal income distribution, underdeveloped welfare state and poor public services (the average Gini coefficient was 0.42 ). In these group of countries public social expenditures were very low (the average social expenditure at the end of each dictatorship, sometime in the 1970 s, was only $14 \%$ of GDP, and the average public health care expenditure was only $4.8 \%$ of GDP). It should be stressed however that in the years that followed, democracy was established in these countries and their average public social expenditure and average public health care expenditure were close to those of the liberal 
tradition (see, Navarro, 1989, 2002) while more recently health expenditure has amounted to $8.7 \%$ of GDP (Morgan et al. 2017).

\section{Data and methodology}

We investigate the effects of government health expenditure and government party political orientation on health outcomes by estimating an unbalanced panel with annual data for the period 2000-2018. We focus on 15 countries of the G20 group ${ }^{1}$ (Argentina, Australia, Brazil, Canada, France, Germany, India, Italy, Japan, Korea Republic, Mexico, South Africa, Spain, United Kingdom, USA).

Our baseline regression model is:

$$
\text { health }_{i t}=\alpha_{i}+\beta_{1} \text { govhealthex }_{i t}+\beta_{2} \text { inequality }_{i t}+\beta_{3} \text { unemployment }_{i t}+\beta_{4} \text { education }_{i t}+\beta_{5} \mathbf{X}_{i t}+\varepsilon_{i t}
$$

where health denotes health outcomes captured by infant mortality, govehealthex denotes government health expenditure as a percentage of GDP, inequality denotes a Gini index of income inequality in equivalized household disposable income developed by Solt (2020), unemployment is the unemployment rate, and education is secondary school enrolment.

Equation (1) also includes a vector $\mathbf{X}$ that consists of dummy variables that capture government party orientation with respect to economic policy which are constructed using data from the Database of Political Institutions 2020 (Cruz et al., 2021). Specifically, right is a dummy variable that takes the value 1 if the government party is defined as right (conservative, Christian democratic, right-wing) and 0 otherwise (Model 1); centre takes the value 1 if the government party position can best be described as Centrist and 0 otherwise (Model 3); and left takes the value 1 if the government party is left (communist, socialist, social democratic, left-wing) and 0 otherwise (Model 5). Furthermore, by interacting the types of political party in power with government health expenditure, we explore the

\footnotetext{
${ }^{1}$ Our effort to use data for all the G20 countries and a longer time period was hampered by data availability.
} 
potential effect that may be manifested through the impact of the interacting terms (Models 2, 4, 6). Table A1 in the Appendix presents detailed descriptions of all variables and their sources, while Tables A2 and A3 provide descriptive statistics and the correlation matrix. Traditional regression techniques (e.g. OLS) measure differences in the dependent variable between populations at the mean and in this setting the fundamental assumption made is that the regression coefficients are constant across the population. However, in some cases we are interested to investigate if the independent variables have varying effects at different points in the conditional distribution of the dependent variable, rather than only at the mean. This is important in our context since it is reasonable to expect that the effect of government health expenditure may differ across quantiles of the conditional distribution of the health outcome variable. To this end, we employ a quantile panel estimator with nonadditive fixed effects which produces estimates at different points of the conditional distribution of the dependent variable which are considered to be more robust to nonnormal errors and outliers.

Many panel quantile estimators include additive fixed effects in the quantile function and provide estimates about the distribution of $\left(Y_{i t}-\mu_{i} \mid Z_{i t}\right)$, where $Y_{i t}$ is the outcome variable, $Z_{i t}$ are treatment variables (exogenous or endogenous), and $\mu_{i}$ denotes the fixed effects. However, observations at the top of $\left(Y_{i t}-\mu_{i}\right)$, may actually be at the bottom of the $Y_{i t}$ distribution and, subsequently, additive fixed effect models can provide information about the outcome relative to fixed effect distribution rather than the effects of the treatment variables on the outcome distribution. In this paper we employ Powell's (2016) panel data quantile estimator with nonadditive fixed effects that provides estimates for the distribution of $\left(Y_{i t} \mid Z_{i t}\right)$, while allowing for individual level heterogeneity and maintaining the nonseparable disturbance term typically used in quantile estimation. The quantile panel estimator with nonadditive fixed effects produces estimates which are consistent for small $T$ and can be 
interpreted in the same manner as cross-sectional quantile estimates, i.e. the impact of the explanatory variables on a quantile of the outcome distribution.

\section{Results and discussion}

We use infant mortality as a proxy for health outcomes and as implied by the quantile methodology adopted, we estimate alternative models at different point of the distribution $(0.10,0.25,0.50,0.75,0.90)$. In Models 1,3 , and 5 (Tables $1,2,3)$ the four control variables are common in all models whilst the party orientation dummies are inserted one at a time. In Models 2, 4, and 6 we use the same rationale as previously but this time the party dummy variables are interacted with government health expenditure in order to capture the mediating effect of party orientation through government health expenditure on infant mortality.

\section{[Tables 1, 2, 3 about here]}

The results indicate that a first key finding is the paramount and highly significant role that government health expenditure, income inequality, and party orientation play in affecting infant mortality. More specifically, the empirical results show that the relationship between government health expenditure (govhealthex) and infant mortality is robust and statistically significant with varying degrees of negative impact across the five quantiles for each of the models estimated. Our results suggest that at least for the set of counties in our sample, effective allocation of government health expenditure will indeed reduce infant mortality a finding in line with Rana et al. (2018), Nicholas et al. (2016), Rahman et al. (2018) and Owusu et al. (2019) but inconsistent with the study of Akinlo and Sulola (2019). Income inequality (inequality) is found to be positive and highly significant across all estimated models and different points of the distribution which is in line with Kawachi and Kennedy (1999) who argue that redistributive economic policies have a substantial impact on social justice and better population health. The proposition that income distribution plays a 
key role in determining population's health, is also explored by Mellor and Milyo (2002), Osler et al. (2002), Shibuya et al. (2002); Deaton and Lubotsky (2003), Lynch et al. (2004), Leigh et al. (2012), Pickett and Wilkinson (2015), Neumayer and Plumper (2016), amongst others. It is therefore envisaged that the countries where policies distribute income more equitably will be boasting a heathier population.

Unemployment is found to have a positive effect across the majority of the estimated models which is in line with Adofu and Salami (2019). It is worth noting here that the broader literature on unemployment proxied by economic downturns and child health has produced mixed evidence (see for instance, Dehejia and Lleras-Muney 2004 and Eiríksdóttir et al. 2013. Furthermore, education has a significantly negative effect however this finding is relatively difficult to be compared against existing studies on the relationship between education and infant mortality as the majority, if not all of these, use survey data that consists of various socio-economic factors such as mother's education, mother's work status, husband's occupation, husband's education, type of place of residence etc. The level of mother's education in a number of this these studies is particularly strongly associated with infant mortality whilst in some others it is the husband's education that is more important (Hobcraft et al., 1984; Arntzen and Andersen, 2004; Gakidou et al., 2010; Andriano et al., 2019).

The party orientation dummies exhibit interesting patterns when they are examined individually or as interaction terms with government health expenditure. In particular, the party right dummy (right) when considered individually appears to be initially negatively related to infant mortality at the 0.10 and 0.25 quantiles respectively, then turns positive and significant at the 0.5 quantile before it becomes again negative and significant at the 0.75 quantile (Table 1, Model 1). When the party interactions are considered, the coefficient of the party right interaction (right $\times$ govhealthex) is negative and significant at the lowest quantile 
0.10 which then changes to positive at quantiles 0.50 and 0.75 (Table 1 , Model 2). The party centre dummy (centre) is found to be positive and significant at the first two quantiles 0.10 and 0.25 before it turns negative at quantiles 0.50 and 0.90 (Table 2, Model 3). The estimates for the interaction term (centre $\times$ govhealthex) are more fragmented since it is found to be negative and highly significant only at the 0.50 quantile (Table 2, Model 4). The party left dummy (left) is found to be positive and significant at the lowest quantile 0.10 before it becomes negative and highly significant at the following three quantiles $0.25,0.50$, and 0.75 (Table 3, Model 5) while the results of the interaction term (left $\times$ govhealthex) are mostly consistent; positive and significant at the lowest quantile 0.10 and change to negative and significant at the following quantiles $0.25,0.50$, and 0.75 (Table 3, Model 6).

Our results to a great extent confirm the view that left-wing governments promote, through health expenditure provision, better health outcomes than under right-wing governments. This is evident in the highly significant coefficients of the individual left party dummy as well as the interaction term in the respective quantiles $(0.25,0.50,0.75)$. In this context,

The fact however that at the lowest quantile 0.10 the interaction term was found to positively affect infant mortality might suggest that certain segments of the society will not benefit from higher spending. Even though it might not directly follow from our results it might be inferred that people at the lowest end of the distribution are unable to strike a balance between individual lifestyle choices versus wider structural factors that shapes their health outcome, hence, being unable to harness the benefits of higher health expenditure.

Overall, the policy implications of our study are of great significance as it raises awareness of the fact that politics do matter and should therefore assume prominence in public health research. It is impossible to understand health outcomes without acknowledging 
the ideological differences between governments. Our study clearly suggests that state administrations, such as left-wing governments, that favour redistributional policies (through more progressive tax systems and universal welfare cultures) are more likely to be associated with improved population health outcomes such as lower rates of infant mortality. Policy makers need to understand that the assumption that democratic systems serve as an automatic remedy of ailments, is mostly a misconception. Infant mortality can only be reduced by the right mix of government policies. Well-designed policies that aim at boosting social and health expenditure should be envisaged as the precursors of improved health outcomes.

\section{Conclusions}

Arguably, government healthcare expenditure is one of the most important components of total government expenditure in advanced economies and potentially one of the most controversial topics in the political discourse. The notion that partisan ideology is associated with changes in health expenditure in the OECD (Herwartz and Theilen, 2014) provided the impetus for this study to assess its mediating effect on health outcomes.

Research on the social determinants of health (Braveman et al., 2011) has highlighted how environmental and societal factors can shape health outcomes. Insights into the institutional aspects of racism and discrimination and their concomitant impact on health disparities have also been provided (Bailey et al., 2017). In this study we have gone one step further by assessing the political determinants of health as an important, but currently underresearched, determinant of health. We have explored the relationship between the government political party orientation and health outcomes (as proxied by infant mortality) and gauged the mediating effect of party policy via government health outlays on infant mortality. Additional aspects potentially significant for health outcomes such as income inequality, unemployment, and education were also investigated. 
Our findings support the hypothesis that political party orientation affects indicators of population health outcomes such as infant mortality. We find that left-wing parties, when compared to right and centre oriented political parties, contribute to better health outcomes. In addition, the impact of redistributing policies (as reflected by the highly significant Gini coefficient) appears to be of a paramount importance in alleviating infant mortality whilst both education and unemployment incrementally reinforce the premise that more education and lower unemployment can lead to better health outcomes.

Setting priorities for health spending has been at the forefront of research for decades and health policy researchers have been trying to come up with the proper formula that could be used to effectively plan health care expenditure policies. Despite the existing limitations that relate to the measures of burden - that emphasize mortality or health expenditure - it is apparent that no formulas or broad principles can be used in lieu of a political process when determining priorities in health care expenditure. When it comes to which party ideology favours a more equitable and healthy society, left-wing ideology appears to dominate the theoretical we well as empirical discourse of academic analysis. The question, however, is not to get entangled into party politics that most of the time are dominated by vested interests but rather to devise a political process that is not dominated by those with greater wealth and position of power. We should find a way to a process that is fair and transparent given the history of health policy across the world. 


\section{References}

Acemoglu, D. and Robinson, J.A., 2006. Economic origins of dictatorship and democracy. Cambridge University Press, New York.

Acemoglu, D., Naidu, S., Restrepo, P. and Robinson, J.A., 2019. Democracy does cause growth. Journal of Political Economy, 127(1), pp. 47-100.

Adam, T., Hsu, J., De Savigny, D., Lavis, J.N., Røttingen, J.A. and Bennett, S., 2012. Evaluating health systems strengthening interventions in low-income and middleincome countries: are we asking the right questions?. Health Policy and Planning, 27(suppl_4), pp.iv9-iv19.

Adofu, I. and Salami, A., 2019. Unemployment and mortality rates in Nigeria: a cointegration approach. Lafia Journal of Economics and Management Sciences, 3(2), pp.22-42.

Akinlo, A.E. and Sulola, A.O., 2019. Health care expenditure and infant mortality in subSaharan Africa. Journal of Policy Modeling, 41(1), pp.168-178.

Andriano, L. and Monden, C.W., 2019. The causal effect of maternal education on child mortality: Evidence from a quasi-experiment in Malawi and Uganda. Demography, 56(5), pp.1765-1790.

Arntzen, A. and Andersen, A.M.N., 2004. Social determinants for infant mortality in the Nordic countries, 1980-2001. Scandinavian Journal of Public Health, 32(5), pp.381389.

Bailey, Z.D., Krieger, N., Agénor, M., Graves, J., Linos, N. and Bassett, M.T., 2017. Structural racism and health inequities in the USA: evidence and interventions. The Lancet, 389(10077), pp.1453-1463.

Bambra, C., 2005. Cash versus services:'worlds of welfare'and the decommodification of cash benefits and health care services. Journal of Social Policy, 34(2), pp.195-213. 
Barnish, M.S. and Turner, S., 2017. The value of pragmatic and observational studies in health care and public health. Pragmatic and Observational Research, 8, p.49-55.

Braveman, P., Egerter, S. and Williams, D.R., 2011. The social determinants of health: coming of age. Annual Review of Public Health, 32(1), pp.381-398.

Brown, T.M., Cueto, M. and Fee, E., 2006. The World Health Organization and the transition from "international" to "global" public health. American Journal of Public Health, 96(1), pp.62-72.

Cameron, D., 1984. Social democracy, corporatism, and labor quiescence: The presentation of interests in advanced capitalist societies. In Goldthorpe, John H. (ed.) Order and Conflict in Contemporary Capitalism. Oxford: Clarendon Press; 143-178.

Castles, F.G., 1982. The impact of parties: Politics and policies in democratic capitalist states. London; Beverly Hills, Calif.: Sage Publications.

Castles, F.G., 2000. Comparative public policy: Patterns of post-war transformation. Cheltenham: Edward Elgar.

Crepaz, M.M., 1998. Inclusion versus exclusion: Political institutions and welfare expenditures. Comparative Politics, 31(1), pp.61-80.

Cruz, C., Keefer, P., and Scartascini, C. (2021). Database of political institutions 2020. InterAmerican Development Bank Research Department.

\section{$\underline{\text { http://dx.doi.org/10.18235/0003049 }}$}

Deaton, A. and Lubotsky, D., 2003. Mortality, inequality and race in American cities and states. Social Science \& Medicine, 56(6), pp.1139-1153.

Esping-Andersen, G., 1990. The three worlds of welfare capitalism. Princeton: Princeton University Press.

Dehejia, R. and Lleras-Muney, A., 2004. Booms, busts, and babies' health. The Quarterly Journal of Economics, 119(3), pp.1091-1130. 
Eiríksdóttir, V.H., Ásgeirsdóttir, T.L., Bjarnadóttir, R.I., Kaestner, R., Cnattingius, S. and Valdimarsdóttir, U.A., 2013. Low birth weight, small for gestational age and preterm births before and after the economic collapse in Iceland: a population based cohort study. PloS one, 8(12), p.e80499.

Ferrie, J.E., 2015. Evidence and policy: mind the gap. International Journal of Epidemiology, 44(1), pp.1-7.

Gakidou, E., Cowling, K., Lozano, R. and Murray, C.J., 2010. Increased educational attainment and its effect on child mortality in 175 countries between 1970 and 2009: a systematic analysis. The Lancet, 376(9745), pp.959-974.

Gilson, L. and Raphaely, N., 2008. The terrain of health policy analysis in low and middle income countries: a review of published literature 1994-2007. Health Policy and Planning, 23(5), pp.294-307.

Gomez, E., 2016. Introduction: The state of political science research in global health politics and policy. Global Health Governance, 10(3), pp.3-8.

Hansen, H., Holmes, S. and Lindemann, D., 2013. Ethnography of health for social change: impact on public perception and policy. Social Science \& Medicine, 99(December), pp.116-118.

Hiam, L., Dorling, D., Harrison, D. and McKee, M., 2017. What caused the spike in mortality in England and Wales in January 2015?. Journal of the Royal Society of Medicine, 110(4), pp.131-137.

Hibbs Jr, D.A., 1977. Political parties and macroeconomic policy. The American Political Science Review, 71, pp.1467-1487.

Hicks, A.M. and Swank, D.H., 1992. Politics, institutions, and welfare spending in industrialized democracies, 1960-82. The American Political Science Review, 86, pp.658-674. 
Hobcraft, J.N., McDonald, J.W. and Rutstein, S.O., 1984. Socio-economic factors in infant and child mortality: a cross-national comparison. Population Studies, 38(2), pp.193223.

Immergut, E.M., 1992. Health politics: interests and institutions in Western Europe. Cambridge: Cambridge University Press.

Kleinman, A., 2010. Four social theories for global health. The Lancet, 375(9725), pp.15181519.

Korpi, W., 2000. Faces of inequality: Gender, class, and patterns of inequalities in different types of welfare states. Social Politics: International Studies in Gender, State \& Society, 7(2), pp.127-191.

Lee, K., 2010. How do we move forward on the social determinants of health: the global governance challenges. Critical Public Health, 20(1), pp.5-14.

Lee, K., 2015. Revealing power in truth: Comment on" Knowledge, moral claims and the exercise of power in global health". International Journal of Health Policy and Management, 4(4), pp.257-259.

Leigh, A., Jencks, C. and Smeeding, T.M., 2012. Health and economic inequality. In Nolan, B, Salverda, W., Smeeding, T.M. (Eds), The Oxford Handbook of Economic Inequality, pp.384-405, Oxford University Press.

Lijphart, A., 2012. Patterns of democracy: Government forms and performance in thirty-six countries. New Haven: Yale University Press.

Luxembourg Income Study. (2006) Luxembourg income study database. http://www.lisproject.org.

Mackenbach, J. P., 2014. Political determinants of health. The European Journal of Public Health, 24(1), pp.2-2. 
McGuire, J., 2010. Political factors and health outcomes: insight from Argentina's provinces. United Nations Development Programme Human Development Reports, Research Paper 2010/25.

Marten, R., Hanefeld, J. and Smith, R., 2014. Commission on global governance for health: what about power. The Lancet, 383(9936), pp.2207.

Mellor, J. M., and Milyo, J., 2002. Income inequality and health status in the United States: evidence from the current population survey. Journal of Human Resources, pp.510539.

Muntaner, C., Borrell, C., Ng, E., Chung, H., Espelt, A., Rodriguez-Sanz, M., Benach, J. and O’Campo, P., 2011. Politics, welfare regimes, and population health: controversies and evidence. Sociology of Health \& Illness, 33(6), pp.946-964.

Navarro, V., Muntaner, C., Borrell, C., Benach, J., Quiroga, Á., Rodríguez-Sanz, M., Vergés, N. and Pasarín, M.I., 2006. Politics and health outcomes. The Lancet, 368(9540), pp.1033-1037.

Navarro, V., 2008. Politics and health: a neglected area of research. European Journal of Public Health, 18(4), pp.354-355.

Nicholas, A., Edward, N.A. and Bernardin, S., 2016. The effect of health expenditure on selected maternal and child health outcomes in Sub-Saharan Africa. International Journal of Social Economics, 43(12), 1386-1399.

Neumayer, E. and Plumper, T., 2016. Inequalities of income and inequalities of longevity: a cross-country study. American Journal of Public Health, 106(1), pp.160-165.

Morgan, D., Gmeinder, M. and Wilkens, J., 2017. An OECD analysis of health spending in Norway, Working Paper DELSA/HEA/WD/HWP(2017)1 OECD.

OECD, 2017. Health statistics (http://www.oecd.org/health/healthdata) 
Ooms, G., 2014. From international health to global health: how to foster a better dialogue between empirical and normative disciplines. BMC International Health and Human Rights, 14(1), pp.1-10.

Okada, K., 2018. Health and political regimes: Evidence from quantile regression. Economic Systems, 42(2), pp.307-319.

Osler, M., Prescott, E., Gr, M., Christensen, U., Due, P. and Engholm, G., 2002. Income inequality, individual income, and mortality in Danish adults: analysis of pooled data from two cohort studies. British Medical Journal, 324(7328), p.13.

Ottersen, O.P., Frenk, J. and Horton, R., 2011. The Lancet-University of Oslo commission on global governance for health, in collaboration with the Harvard Global Health Institute. The Lancet, 378(9803), pp.1612-1613.

Owusu, P.A., Sarkodie, S.A. and Pedersen, P.A., 2021. Relationship between mortality and health care expenditure: Sustainable assessment of health care system. Plos one, 16(2), p.e0247413.

Parker, R. and Garcia, J., 2018. Routledge Handbook on the politics of global health. London and New York: Routledge.

Rana, R.H., Alam, K. and Gow, J., 2018. Health expenditure, child and maternal mortality nexus: a comparative global analysis. BMC International Health and Human Rights, 18(1), pp.1-15.

Pickett, K. and Wilkinson, R., 2015. Income inequality and health: a causal review. Social Science \& Medicine, 128, pp.316-326.

Powell, D., 2016. Quantile regression with nonadditive fixed effects. Available at: https://sites.google.com/site/davidmatthewpowell/working-papers 
Przeworski, A., Alvarez, M.E., Cheibub, J.A., Limongi, F., 2000. Democracy and development: Political institutions and well-being in the world, 1950-1990. New York: Cambridge University Press.

Rahman, M.M., Khanam, R. and Rahman, M., 2018. Health care expenditure and health outcome nexus: new evidence from the SAARC-ASEAN region. Globalization and Health, 14(1), pp.1-11.

Raphael, D. and Bryant, T., 2004. The welfare state as a determinant of women's health: support for women's quality of life in Canada and four comparison nations. Health Policy, 68(1), pp.63-79.

Reijneveld, S.A., 2017. The return of community-based health and social care to local government: governance as a public health challenge. European Journal of Public Health 27(1).

Rowlingson, K., 2011. Does income inequality cause health and social problems? York: Joseph Rowntree Foundation.

Scott-Samuel, A., Bambra, C., Collins, C., Hunter, D.J., McCartney, G. and Smith, K., 2014. The impact of Thatcherism on health and well-being in Britain. International Journal of Health Services, 44(1), pp.53-71.

Schmidt, M.G., 1996. When parties matter: A review of the possibilities and limits of partisan influence on public policy. European Journal of Political Research, 30(2), pp.155183.

Shiffman, J., 2014. Knowledge, moral claims and the exercise of power in global health. International Journal of Health Policy and Management, 3(6), p.297-299.

Shibuya, K., Hashimoto, H. and Yano, E., 2002. Individual income, income distribution, and self rated health in Japan: cross sectional analysis of nationally representative sample. British Medical Journal, 324(7328), p.16. 
Solt, F., 2020. Measuring income inequality across countries and over time: The standardized world income inequality database. Social Science Quarterly, 101(3), pp.1183-1199.

Storeng, K. T., and Mishra, A., 2014. Politics and practices of global health: Critical ethnographies of health systems. Global Public Health, 9(8), pp.858-864.

Subramanian, S.V., Huijts, T. and Perkins, J.M., 2009. Association between political ideology and health in Europe. The European Journal of Public Health, 19(5), pp. $455-457$.

Tsebelis, G., 2002. Veto players: How political institutions work. Princeton: Princeton University Press.

UN News, 2019. UN welcomes 'most comprehensive agreement ever' on global health. Available at: https://news.un.org/en/story/2019/09/1047032.

Wagschal, U. (1997). Direct Democracy and Public Policymaking. Journal of Public Policy, 17(2), pp.223-245.

Watkins, J., Wulaningsih, W., Da Zhou, C., Marshall, D.C., Sylianteng, G.D., Rosa, P.G.D., Miguel, V.A., Raine, R., King, L.P. and Maruthappu, M., 2017. Effects of health and social care spending constraints on mortality in England: a time trend analysis. $B M J$ open, $7(11)$.

World Health Organization, (2008). Closing the gap in a generation: health equity through Action on the social determinants of health. Geneva: World Health Organization.

World Health Organization, 2018. Health inequities and their causes. Available at: https://www.who.int/news-room/facts-in-pictures/detail/health-inequities-and-theircauses

World Health Organization, 2019. Universal health coverage and health financing. Available at: https://www.who.int/health_financing/universal_coverage_definition/en/ 
Wilkinson, R. and Pickett, K., 2010. The spirit level: why equality is better for everyone. London: Penguin.

Youde, J., 2005. Enter the fourth horseman: health security and international relations theory. The Whitehead Journal of Diplomacy and International Relations, 6(1), pp.193-208. 


\section{Tables}

Table 1. Panel quantile results for right government party policy orientation

\begin{tabular}{|c|c|c|c|c|c|}
\hline \multicolumn{6}{|c|}{ Model 1} \\
\hline Quantile & 0.1 & 0.25 & 0.5 & 0.75 & 0.9 \\
\hline govhealthex & $\begin{array}{l}\mathbf{- 0 . 2 9 7 * * *} \\
(0.078)\end{array}$ & $\begin{array}{l}\mathbf{- 0 . 4 4 4 * * *} \\
(0.032)\end{array}$ & $\begin{array}{l}-\mathbf{0 . 4 7 4 * *} \\
(0.238)\end{array}$ & $\begin{array}{l}\mathbf{- 0 . 3 5 6 * * *} \\
(0.089)\end{array}$ & $\begin{array}{l}\mathbf{- 2 . 8 3 9 * * *} \\
(0.778)\end{array}$ \\
\hline inequality & $\begin{array}{l}\mathbf{0 . 8 4 4 * * *} \\
(0.045)\end{array}$ & $\begin{array}{l}\mathbf{0 . 7 5 3 * * *} \\
(0.009)\end{array}$ & $\begin{array}{l}\mathbf{0 . 7 0 8 * * *} \\
(0.027)\end{array}$ & $\begin{array}{l}\mathbf{0 . 5 8 2 * * *} \\
(0.046)\end{array}$ & $\begin{array}{l}\mathbf{0 . 8 5 0} * * * \\
(0.092)\end{array}$ \\
\hline unemployment & $\begin{array}{l}0.002 \\
(0.031)\end{array}$ & $\begin{array}{l}\mathbf{0 . 0 8 0} * * * \\
(0.006)\end{array}$ & $\begin{array}{l}\mathbf{0 . 1 9 7 * * *} \\
(0.052)\end{array}$ & $\begin{array}{l}\mathbf{0 . 6 9 1 * * *} \\
(0.044)\end{array}$ & $\begin{array}{l}\mathbf{0 . 0 9 8 * * *} \\
(0.019)\end{array}$ \\
\hline education & $\begin{array}{l}\mathbf{- 0 . 0 6 9 * * *} \\
(0.021)\end{array}$ & $\begin{array}{l}\mathbf{- 0 . 0 8 5 * * *} \\
(0.005)\end{array}$ & $\begin{array}{l}-\mathbf{0 . 0 7 6} * * * \\
(0.022)\end{array}$ & $\begin{array}{l}\mathbf{- 0 . 2 5 5 * * *} \\
(0.018)\end{array}$ & $\begin{array}{l}0.073 \\
(0.118)\end{array}$ \\
\hline right & $\begin{array}{l}\mathbf{- 0 . 6 1 1 * *} \\
(0.242)\end{array}$ & $\begin{array}{l}\mathbf{- 0 . 6 7 5 * * *} \\
(0.146)\end{array}$ & $\begin{array}{l}\mathbf{0 . 6 7 4 * *} \\
(0.287)\end{array}$ & $\begin{array}{l}-\mathbf{0 . 7 3 4 * * *} \\
(0.137)\end{array}$ & $\begin{array}{l}0.905 \\
(0.657)\end{array}$ \\
\hline
\end{tabular}

Model 2

\begin{tabular}{llllll}
\hline Quantile & $\mathbf{0 . 1}$ & $\mathbf{0 . 2 5}$ & $\mathbf{0 . 5}$ & $\mathbf{0 . 7 5}$ & $\mathbf{0 . 9}$ \\
\hline govhealthex & $\mathbf{- 0 . 4 8 1 * * *}$ & $\mathbf{- 0 . 3 3 6} * * *$ & $\mathbf{- 0 . 3 1 2} * * *$ & $\mathbf{- 0 . 2 3 4} * * * *$ & $\mathbf{- 2 . 6 8 5} * * *$ \\
& $(0.042)$ & $(0.106)$ & $(0.068)$ & $(0.049)$ & $(0.354)$ \\
inequality & $\mathbf{0 . 8 0 9} * * *$ & $\mathbf{0 . 7 0 0} * * *$ & $\mathbf{0 . 6 7 6} * * *$ & $\mathbf{0 . 8 0 0} * * *$ & $\mathbf{0 . 7 2 1} * * *$ \\
& $(0.032)$ & $(0.034)$ & $(0.029)$ & $(0.009)$ & $(0.099)$ \\
unemployment & -0.011 & -0.072 & $\mathbf{0 . 1 6 0} * * *$ & $\mathbf{0 . 5 4 1} * * *$ & $\mathbf{0 . 3 2 6} * *$ \\
& $(0.059)$ & $(0.095)$ & $(0.025)$ & $(0.024)$ & $(0.141)$ \\
education & $\mathbf{- 0 . 0 7 5} * * *$ & -0.050 & $\mathbf{- 0 . 0 9 2} * * *$ & $\mathbf{- 0 . 1 3 4} * * *$ & -0.031 \\
& $(0.011)$ & $(0.048)$ & $(0.006)$ & $(0.004)$ & $(0.044)$ \\
right $\times$ govhealthex & $\mathbf{- 0 . 1 3 5 * * *}$ & -0.020 & $\mathbf{0 . 1 0 0} * * *$ & $\mathbf{0 . 0 5 2} * * *$ & 0.100 \\
& $(0.021)$ & $(0.048)$ & $(0.019)$ & $(0.007)$ & $(0.099)$ \\
\hline
\end{tabular}

Notes: 206 observations in total. Standard errors in parentheses. The adaptive Markov Chain Monte Carlo optimization procedure is employed with 1000 draws. ***,** and * denote statistical significance at the 1,5 and $10 \%$ level, respectively. 
Table 2. Panel quantile results for centre government party policy orientation

\begin{tabular}{|c|c|c|c|c|c|}
\hline \multicolumn{6}{|c|}{ Model 3} \\
\hline Quantile & 0.1 & 0.25 & 0.5 & 0.75 & 0.9 \\
\hline \multirow[t]{2}{*}{ govhealthex } & $-0.519 * * *$ & $-\mathbf{0 . 3 8 1} * * *$ & $-1.178^{*}$ & $-0.531 * * *$ & $-2.493 * * *$ \\
\hline & $(0.067)$ & $(0.033)$ & $(0.614)$ & $(0.073)$ & $(0.190)$ \\
\hline \multirow[t]{2}{*}{ inequality } & $0.781 * * *$ & $0.819 * * *$ & $0.608 * * *$ & $\mathbf{0 . 7 5 5 * * *}$ & $0.765 * * *$ \\
\hline & $(0.033)$ & $(0.007)$ & $(0.074)$ & $(0.013)$ & $(0.053)$ \\
\hline \multirow[t]{2}{*}{ unemployment } & -0.010 & -0.003 & $0.392 *$ & $0.523 * * *$ & 0.053 \\
\hline & $(0.066)$ & $(0.011)$ & $(0.225)$ & (0.009) & $(0.047)$ \\
\hline education & $\begin{array}{l}-\mathbf{0 . 0 8 7} * * * \\
(0.015)\end{array}$ & $\begin{array}{l}-\mathbf{0 . 0 5 0} * * * \\
(0.005)\end{array}$ & $\begin{array}{l}-\mathbf{0 . 0 9 7} * * * \\
(0.018)\end{array}$ & $\begin{array}{l}-\mathbf{0 . 1 1 6} * * * \\
(0.003)\end{array}$ & $\begin{array}{l}\mathbf{- 0 . 1 5 1} * * * \\
(0.010)\end{array}$ \\
\hline centre & $\begin{array}{l}\mathbf{0 . 9 8 0} * * * \\
(0.217)\end{array}$ & $\begin{array}{l}\mathbf{0 . 8 5 4} * * * \\
(0.224)\end{array}$ & $\begin{array}{l}-1.337 * * \\
(0.663)\end{array}$ & $\begin{array}{l}\mathbf{0 . 7 5 6} \\
(0.759) \\
\end{array}$ & $\begin{array}{l}-\mathbf{1 3 . 3 8 6}^{* * * *} \\
(1.164)\end{array}$ \\
\hline \multicolumn{6}{|c|}{ Model 4} \\
\hline Quantile & 0.1 & 0.25 & 0.5 & 0.75 & 0.9 \\
\hline govhealthex & $\begin{array}{l}-\mathbf{0 . 4 9 9} * * * \\
(0.147)\end{array}$ & $\begin{array}{l}\mathbf{- 0 . 5 5 3 * * *} \\
(0.040)\end{array}$ & $\begin{array}{l}\mathbf{- 0 . 4 1 9 * * *} \\
(0.155)\end{array}$ & $\begin{array}{l}-\mathbf{1 . 5 0 3} * * \\
(0.604)\end{array}$ & $\begin{array}{l}\mathbf{- 2 . 4 6 5 * * *} \\
(0.646)\end{array}$ \\
\hline inequality & $\begin{array}{l}\mathbf{0 . 6 5 9} * * * * \\
(0.089)\end{array}$ & $\begin{array}{l}\mathbf{0 . 7 9 9} * * * \\
(0.017)\end{array}$ & $\begin{array}{l}\mathbf{0 . 6 8 6} * * * \\
(0.038)\end{array}$ & $\begin{array}{l}\mathbf{1 . 1 6 3} * * * \\
(0.199)\end{array}$ & $\begin{array}{l}\mathbf{0 . 7 9 6 * * *} \\
(0.159)\end{array}$ \\
\hline unemployment & $\begin{array}{l}-0.020 \\
(0.054)\end{array}$ & $\begin{array}{l}-0.004 \\
(0.043)\end{array}$ & $\begin{array}{l}\mathbf{0 . 1 2 4 *} \\
(0.065)\end{array}$ & $\begin{array}{l}0.110 \\
(0.180)\end{array}$ & $\begin{array}{l}0.280 \\
(0.193)\end{array}$ \\
\hline education & $\begin{array}{l}-\mathbf{0 . 0 8 3} * * * * \\
(0.021)\end{array}$ & $\begin{array}{l}-0.018 \\
(0.027)\end{array}$ & $\begin{array}{l}-\mathbf{0 . 1 0 4} * * * \\
(0.007)\end{array}$ & $\begin{array}{l}0.059 \\
(0.088)\end{array}$ & $\begin{array}{l}0.012 \\
(0.076)\end{array}$ \\
\hline cenrte $\times$ govhealthex & $\begin{array}{l}0.194 \\
(0.148)\end{array}$ & $\begin{array}{l}-\mathbf{- 0 . 1 1 5 *} \\
(0.059)\end{array}$ & $\begin{array}{l}-\mathbf{0 . 3 6 9} * * * \\
(0.040)\end{array}$ & $\begin{array}{l}-0.270 \\
(0.948)\end{array}$ & $\begin{array}{l}0.495 \\
(1.852)\end{array}$ \\
\hline
\end{tabular}

Notes: See notes Table 1 
Table 3. Panel quantile results for left government party policy orientation

\begin{tabular}{|c|c|c|c|c|c|}
\hline \multicolumn{6}{|c|}{ Model 5} \\
\hline Quantile & 0.1 & 0.25 & 0.5 & 0.75 & 0.9 \\
\hline \multirow[t]{4}{*}{ govhealthex } & $-0.453 * * *$ & -0.019 & $-0.481 * * *$ & $-0.119 * * *$ & $-2.299 * * *$ \\
\hline & $(0.095)$ & $(0.080)$ & $(0.153)$ & $(0.030)$ & $(0.816)$ \\
\hline & $0.869 * * *$ & $0.797 * * *$ & $0.774 * * *$ & $0.826 * * *$ & $0.828 * * *$ \\
\hline & $(0.043)$ & $(0.021)$ & $(0.064)$ & $(0.005)$ & $(0.148)$ \\
\hline \multirow[t]{2}{*}{ unemployment } & 0.011 & $-0.039 * * *$ & $0.372 * * *$ & $0.424 * * *$ & 0.165 \\
\hline & $(0.039)$ & $(0.011)$ & $(0.128)$ & $(0.010)$ & $(0.194)$ \\
\hline \multirow[t]{2}{*}{ education } & $-0.078 * * *$ & $-0.089 * * *$ & -0.025 & $-0.131 * * *$ & -0.012 \\
\hline & $(0.015)$ & $(0.012)$ & $(0.038)$ & $(0.003)$ & $(0.074)$ \\
\hline \multirow[t]{2}{*}{ left } & $0.807 * * *$ & $-0.766 * * *$ & $-0.960 * *$ & $-0.083 * *$ & -0.320 \\
\hline & $(0.231)$ & $(0.216)$ & $(0.455)$ & $(0.039)$ & $(0.738)$ \\
\hline \multicolumn{6}{|c|}{ Model 6} \\
\hline Quantile & 0.1 & 0.25 & 0.5 & 0.75 & 0.9 \\
\hline govhealthex & $\begin{array}{l}-\mathbf{- 0 . 6 0 3} * * * \\
(0.033)\end{array}$ & $\begin{array}{l}0.062 \\
(0.115)\end{array}$ & $\begin{array}{l}\mathbf{- 0 . 1 2 3 * * *} \\
(0.037)\end{array}$ & $\begin{array}{l}\mathbf{- 0 . 1 5 5 * * *} \\
(0.009)\end{array}$ & $\begin{array}{l}\mathbf{- 1 . 6 8 7 * * *} \\
(0.325)\end{array}$ \\
\hline inequality & $\begin{array}{l}\mathbf{0 . 8 0 7} * * * * \\
(0.013)\end{array}$ & $\begin{array}{l}\mathbf{0 . 9 2 3 * * *} \\
(0.050)\end{array}$ & $\begin{array}{l}\mathbf{0 . 6 9 7} * * * \\
(0.011)\end{array}$ & $\begin{array}{l}\mathbf{0 . 8 3 0} * * * \\
(0.002)\end{array}$ & $\begin{array}{l}1.229 * * * \\
(0.221)\end{array}$ \\
\hline unemployment & $\begin{array}{l}-0.020 \\
(0.032)\end{array}$ & $\begin{array}{l}\mathbf{- 0 . 1 0 2} * \\
(0.057)\end{array}$ & $\begin{array}{l}\mathbf{0 . 1 5 5 * * *} \\
(0.018)\end{array}$ & $\begin{array}{l}\mathbf{0 . 4 5 9} * * * * \\
(0.008)\end{array}$ & $\begin{array}{l}-0.073 \\
(0.167)\end{array}$ \\
\hline education & $\begin{array}{l}-\mathbf{0 . 0 8 9} * * * \\
(0.003)\end{array}$ & $\begin{array}{l}\mathbf{- 0 . 0 5 9} * * \\
(0.025)\end{array}$ & $\begin{array}{l}-\mathbf{0 . 0 9 3} * * * \\
(0.004)\end{array}$ & $\begin{array}{l}-\mathbf{0 . 1 3 5} * * * \\
(0.002)\end{array}$ & $\begin{array}{l}0.106 \\
(0.122)\end{array}$ \\
\hline left $\times$ govhealthex & $\begin{array}{l}\mathbf{0 . 1 0 0 * * *} \\
(0.015)\end{array}$ & $\begin{array}{l}-\mathbf{0 . 0 7 7} * * \\
(0.035)\end{array}$ & $\begin{array}{l}-\mathbf{0 . 0 8 1} * * * \\
(0.010)\end{array}$ & $\begin{array}{l}-\mathbf{0 . 0 2 9} * * * \\
(0.008)\end{array}$ & $\begin{array}{l}0.031 \\
(0.100)\end{array}$ \\
\hline
\end{tabular}

Notes: See notes Table 1 


\section{Appendix}

Table A1. Description of variables

\begin{tabular}{|c|c|c|}
\hline Variable & Definition & Source \\
\hline health & $\begin{array}{l}\text { Infant mortality rate is the number of infants } \\
\text { dying before reaching one year of age per } \\
1,000 \text { live births. }\end{array}$ & World Development Indicators \\
\hline govhealthex & $\begin{array}{l}\text { General government health expenditure from } \\
\text { domestic sources ( } \% \text { of GDP). }\end{array}$ & World Development Indicators \\
\hline inequality & $\begin{array}{l}\text { Gini index of inequality based on household } \\
\text { disposable (post-tax, post-transfer) income. }\end{array}$ & $\begin{array}{l}\text { Standardized World Income } \\
\text { Inequality Database } 9.0 \text { (Solt, } \\
2020 \text { ) }\end{array}$ \\
\hline unemployment & Unemployment ( $\%$ of total labour force). & World Development Indicators \\
\hline education & School enrolment, secondary (\% gross). & World Development Indicators \\
\hline right & $\begin{array}{l}\text { Government party economic policy orientation } \\
\text { dummy variable that takes the value } 1 \text { if the } \\
\text { government party is right (conservative, } \\
\text { Christian democratic, right-wing) and } 0 \\
\text { otherwise. }\end{array}$ & $\begin{array}{l}\text { Constructed by the authors } \\
\text { using data from the Database of } \\
\text { Political Institutions } 2020 \text { (Cruz } \\
\text { et al., 2021) }\end{array}$ \\
\hline centre & $\begin{array}{l}\text { Government party economic policy orientation } \\
\text { dummy variable that takes the value } 1 \text { if the } \\
\text { government party can be described as Centrist } \\
\text { and } 0 \text { otherwise. }\end{array}$ & $\begin{array}{l}\text { Constructed by the authors } \\
\text { using data from the Database of } \\
\text { Political Institutions } 2020 \text { (Cruz } \\
\text { et al., 2021) }\end{array}$ \\
\hline left & $\begin{array}{l}\text { Government party economic policy orientation } \\
\text { dummy variable that takes the value } 1 \text { if the } \\
\text { government party is left (communist, socialist, } \\
\text { social democratic, left-wing) and } 0 \text { otherwise. }\end{array}$ & $\begin{array}{l}\text { Constructed by the authors } \\
\text { using data from the Database of } \\
\text { Political Institutions } 2020 \text { (Cruz } \\
\text { et al., 2021) }\end{array}$ \\
\hline
\end{tabular}

Table A2. Summary statistics

\begin{tabular}{llllll}
\hline Variable & Obs. & Mean & St. Dev. & Min & Max \\
\hline health & 285 & 11.71 & 13.91 & 1.80 & 66.70 \\
govhealthex & 285 & 5.52 & 2.27 & 0.71 & 9.21 \\
inequality & 275 & 37.79 & 9.43 & 26.20 & 63.50 \\
unemployment & 267 & 8.75 & 6.43 & 2.40 & 33.29 \\
education & 233 & 98.59 & 16.0 & 44.87 & 157.20 \\
right & 268 & 0.478 & 0.50 & 0 & 1 \\
centre & 268 & 0.082 & 0.27 & 0 & 1 \\
left & 268 & 0.440 & 0.49 & 0 & 1 \\
\hline
\end{tabular}

Table A3. Correlation matrix

\begin{tabular}{llllll}
\hline Variable & health & govhealthex & inequality & unemployment & education \\
\hline health & 1.00 & & & & \\
govhealthex & -0.66 & 1.00 & & & \\
inequality & 0.88 & -0.63 & 1.00 & & \\
unemployment & 0.49 & -0.12 & 0.57 & 1.00 & 1.00 \\
education & -0.59 & 0.51 & -0.43 & 0.09 &
\end{tabular}

